Edunomika - Vol. 03, No. 01 (Februari 2019)

\title{
ANALISIS PRODUK, BRAND IMAGE, DAN PACKAGING TERHADAP KEPUTUSAN PEMBELIAN KONSUMEN TOKO ROTI WONDER BAKERY DI SURAKARTA
}

\author{
Rangga Indra Fadilla ${ }^{1}$, Ida Aryati DPW ${ }^{2}$, Ratna Damayanti ${ }^{3}$ \\ Program Studi Manajemen Fakultas Ekonomi UNIBA Surakarta \\ rindrafadilla33@gmail.com
}

\begin{abstract}
Abstrak : This study aims to determine the partial and simultaneous influence of Products, Brand Image and Packaging on Purchasing Decisions of Wonder Bakery Bakery Stores in Surakarta. In this study using quantitative research. The population in this study were consumers of Wonder Bakery in Surakarta. The sample in the study amounted to 100 people. The sampling technique uses accidental sampling, which is sampling taken by giving questionnaires to consumers who make the decision to purchase Roti Wonder Bakery in Surakarta. The F test results show that Products, Brand Image and Packaging Against Purchasing Decisions of Consumers of the Wonder Bakery in Surakarta have a simultaneous effect on the decision to buy wonder bread in Surakarta. Based on the results of testing the partial hypothesis, the product has a positive and significant effect on the decision to purchase wonder bakery bread. Brand image has a positive and significant effect on the purchase decision of wonder bakery bread in Jakarta. Packaging has a positive effect on the decision to purchase wonder bakery bread. The results of the coefficient of determination from the results of analysis calculations can be seen that the number of adjustments R2 obtained is 0.625 or $62.5 \%$. This shows that product quality, brand image, and packaging have an effect on snack purchasing decisions at Wonder Bakery.
\end{abstract}

Keywords: Product, promotion, location, purchasing decision

\section{PENDAHULUAN}

Sesuai dengan perkembangan zaman, kini orientasi berpikir Toko Roti Wonder Bakery tidak hanya menciptakan produk unggul saja, namun bagaimana Toko tersebut mampu membuat berbagai variasi jenis Roti untuk mempertahankan cita rasanya yang sulit ditiru oleh toko lain dan menjadikan keputusan pembelian konsumen. Produk merupakan sesuatu yang dapat ditawarkan ke seluruh pasar untuk dipakai sehingga seorang konsumen dapat memuaskan keinganan atau kebutuhannya. Selain produk perusahaan juga harus memperhatikan brand image karena dengan adanya brand image konsumen dapat mengenal suatu produk dan mengetahui seberapa besar kualitas yang dimiliki oleh produk tersebut (Mahera, Suharyono, Musadieq, 2014). Brand image merupakan suatu prestise yang dibutuhkan oleh para konsumen dalam menggunakan suatu produk. Selain memperhatikan brand image maka perusahaan juga harus memperhatikan packaging karena selain menjaga tampilan dari produk juga untuk membedakan sebuah produk dipasar (Mukhtar dan Nurif, 2015). Packaging merupakan suatu seluruh kegiatan memproduksi dan merancang proses pembungkus produk karena packaging atau kemasan memiliki fungsi yang sangat penting. Toko Roti 
Wonder Bakery merupakan salah satu cabang yang berlokasi di Jl. Dr. Rajiman No.460, Bumi, Laweyan, Kota Surakarta, Jawa Tengah 57148. Penataan yang diterapkan di toko dengan penataan yang tersebar diberbagai sudut. Berdasarkan survey maka dapat diketahui bahwa pangsa pasar toko roti yang ada di Surakarta yang paling besar adalah Toko Roti Wonder Bakery sehingga peneliti memutuskan Toko Roti Wonder Bakery di Surakarta sebagai objek penelitian.

\section{LANDASAN TEORI}

Keputusan pembelian merupakan salah satu tindakan yang dilakukan oleh konsumen untuk melakukan pembelian suatu produk yang diinginkan.

Produk merupakan suatu keinginan, kebutuhan dan permintaan manusia memberi kesan adanya produk untuk memenuhi semuanya itu.

Brand Image merupakan suatu nama, symbol, istilah atau desain (rancangan) atau kombinasi yang bermaksud untuk mengenali suatu produk sehingga dapat dibedakan dari produk pesaing lainnya.

Packaging atau kemasan merupakan suatu kegiatan memproduksi dan merancang wadah atau bungkus kemasan suatu produk.

\section{METODOLOGI PENELITIAN}

Jenis penelitian yang digunakan penelitian kuantitatif. Populasi dalam penelitian ini adalah konsumen Toko Wonder Bakery di Surakarta, jumlah sampel dalam penelitian ini 1001 orang. Teknik yang digunakan dalam pengambilan sampel menggunakan metode nonprobability sampling. Data diperoleh dengan menyebar kuesioner. Waktu penelitian dilaksanakan kurang lebih selama 6 bulan dari bulan Agustus 2018 sampai bulan Januari 2019. Teknik analisis data yang digunakan adalah analisis regresi linier berganda, uji t, uji F dan koefisien determinasi.

\section{ANALISIS DATA DAN PEMBAHASAN}

\subsection{ANALISIS DATA}

a. Uji Asumsi Klasik

1) Uji Normalitas

Hasil dari pengujian menunjukan bahwa nilai kolmogrov-smirnov 0,592 dan asymp.sig 0,875 dengan nilai signifikan untuk model regresi lebih besar dari 0,05 maka dapat disimpulkan bahwa data penelitian ini berdistribusi normal.

2) Uji Multikolineritas tujuannya menguji untuk model regresi yang ditemukan adanya lsuatu korelasi antar variabel bebas. Metode yang baik atau tidaknya multikolineritas dengan cara menggunakan nilai variancee inflation factor (VIP), jika nilai tolerancee $\geq 10$ dan nilai VIP $\leq 10$ makaa dapat disimpulkan tidak ada multikolieritas antar variabel bebas.

Tabel 1 Uji Multikolineritas

\begin{tabular}{llll}
\hline Variabel & Tolerance & VIF & Keterangan \\
\hline Produk & 0,776 & 1.289 & $\begin{array}{l}\text { Tidak terjadi } \\
\text { multikolineritas }\end{array}$ \\
$\begin{array}{l}\text { Brand } \\
\text { image }\end{array}$ & 0,752 & 1.329 & $\begin{array}{l}\text { Tidak terjadi } \\
\text { multikolineritas }\end{array}$ \\
\hline
\end{tabular}




\begin{tabular}{llll}
\hline Packaging & 0,898 & 1.114 & $\begin{array}{l}\text { Tidak terjadi } \\
\text { multikolineritas }\end{array}$
\end{tabular}

Dari tabel diatas maka dapat diketahui bahwa variabel produk, brand image, dan packaging tidak terjadi multikolinearitas.

3) Uji Heteroskedastisitas

Tujuannya dapat mengetahui apakah dalam regresi terjadi karena ketidaksamaan variance dari residual satu pengamatan. Pengujian ini dapat menggunakan uji glejser dengan cara meregres nilai ablosute residual terhadap variabel independen. Jika $\mathrm{P}$ value $\geq 0,05$ maka tidak akan terjadi heteroskedastisitas,

Tabel 2. Hasil Uji Heteroskedastisitas

\begin{tabular}{lccc}
\hline Variabel & $\begin{array}{c}\text { P- } \\
\text { Value } \\
(\text { Sig })\end{array}$ & Batas & Keterangan \\
\hline Produk & 0,065 & $\geq 0,05$ & $\begin{array}{l}\text { Tidak terjadi } \\
\text { heteroskedastisitas }\end{array}$ \\
$\begin{array}{l}\text { PBrand } \\
\text { I Image }\end{array}$ & 0,830 & $\geq 0,05$ & $\begin{array}{l}\text { Tidak terjadi } \\
\text { heteroskedastisitas } \\
\text { Packaging }\end{array}$ \\
\end{tabular}

Dari tabel diatas maka dapat diketahui bahwa variabel produk, brand image dan packaging tidak terjadi heteroskedastisitas.

b. Uji Regresi Linier Berganda

Persamaan regresi yang bertujuan untuk mengetahui seberapa besar pengaruh variabel independent produk $\left(\mathrm{X}_{1}\right)$, brand image $\left(\mathrm{X}_{2}\right)$, dan packaging $\left(\mathrm{X}_{3}\right)$ terhadap keputusan pembelian $(\mathrm{Y})$. Hasil dari uji regresi linier berganda dapat dijelaskan pada tabel dibawah ini :

Tabel 3 : Hasil Uji Analisis Linier Berganda

\begin{tabular}{lccccc}
\hline Variabel & B & Beta & $\mathrm{t}_{\text {hitung }}$ & Sig.t & Ket \\
\hline (Constant) & -1.123 & & & & \\
\hline Produk & 0,489 &, 489 & 6,999 &, 000 & Signifikan \\
\hline Brand image & 0,342 &, 342 & 4,823 &, 000 & Signifikan \\
\hline Packaging & 0,197 &, 197 & 3,041 &, 003 & Signifikan \\
\hline $\mathrm{F}_{\text {hitung }}$ & 55,999 & & & & \\
\hline
\end{tabular}




\begin{tabular}{lcl}
\hline Sig F & 0,000 & \\
\hline R Square $\quad 0,625$ & \\
\hline Variabel Dependen & Keputusan Pembelian \\
\hline
\end{tabular}

Berdasarkan analisis diatas maka diperoleh persamaan garis regresinya sebagai berikut :

$$
\mathrm{Y}=-1.123+0,489 \mathrm{X}_{1}+0,342 \mathrm{X}_{2}+0,197 \mathrm{X}_{3}
$$

Keterangan :

1) Didapatkan nilai konstanta -1.123 artinya parameter negative hal ini menunjukan bahwa tanpa adanya variabel produk $\left(\mathrm{X}_{1}\right)$, brand image $\left(\mathrm{X}_{2}\right)$, packaging $\left(\mathrm{X}_{3}\right)$ akan menurun.

2) Koefisien produk bernilai positif yang artinya jika kualitas semakin baik dengan asumsi variabel lain tetap maka keputusan pembelian akan mengalami suatu peningkatan yang sebesar 0,489 .

3) Koefisien brand image bernilai positif yang artinya bahwa jika brand image semakin kuat dengan asumsi variabel lain tetap maka keputusan pembelian akan mengalami peningkatan sebesar 0,342 .

4) Koefisien packaging bernilai positif yang berarti bahwa jika packaging semakin menarik dengan asumsi variabel lain tetap maka keputusan pembelian akan mengalami peningkatan 0,197 .

c. Uji Hipotesis

1) Uji F

Pengujian ini digunakan untuk mengetahui signifikan pengaruhi variabel produk $\left(\mathrm{X}_{1}\right)$, brand image $\left(\mathrm{X}_{2}\right)$, dan packaging $\left(\mathrm{X}_{3}\right)$ secara bersama-sama terhadap keputusan pembelian (Y). hasil uji $F$ pada tabel III diketahui besarnya nilai $F F_{\text {hitung }} \geq f_{\text {tabel }}(55,999) \geq(2,70)$ dengan signifikan $0,000 \leq 0,05$ maka dapat disimpulkan $\mathrm{H}_{0}$ ditolak artinya variabel produk, brand image, dan packaging secara simultan dan signifikan berpengaruh terhadap keputusan pembelian toko wonder bakery disurakarta.

2) Uji t

Digunakan untuk menguji signifikan secara parsial pengaruh variabel independen yang terdiri dari produk $\left(\mathrm{X}_{1}\right)$, brand image $\left(\mathrm{X}_{2}\right)$, dan packaging $\left(\mathrm{X}_{3}\right)$ terhadapi variabel dependen yaitu keputusan pembelian (Y). Berdasarkan hasil analisis penelitian pada Tabel III dapat disimpulkan sebagai berikut:

a) Pada variabel produk $\left(X_{1}\right)$ hasil nilai $t_{\text {hitung }}(6,999) \geq t_{\text {tabel }}(1,984)$ dengan signifikan 0,000 $\leq 0.05$ artinya $\mathrm{H}_{0}$ ditolak secara parsial produk memiliki suatu pengaruh signifikan dan positif terhadap keputusan pembelian roti pada toko roti wonder bakery.

b) 2) Pada variabel brand image $\left(\mathrm{X}_{2}\right)$ hasil nilai $\mathrm{t}_{\text {hitung }}(4,823) \geq \mathrm{t}_{\text {tabel }}(1,984)$ dengan signifikan $0,000 \leq 0.05$ artinya $\mathrm{H}_{0}$ ditolak secara parsial brand image memiliki suatu pengaruh positif dan signifikan terhadap keputusan pembelian roti pada toko roti wonder bakery.

c) 3) Pada variabel packaging $\left(\mathrm{X}_{3}\right)$ hasil nilai $\mathrm{t}_{\text {hitung }}(3,041) \geq \mathrm{t}_{\text {tabel }}(1,984)$ dengan signifikan $0,003 \leq 0,005$ artinya $\mathrm{H}_{0}$ ditolak secara parsial packaging mempunyai suatu pengaruh 
Rangga Indra Fadilla, dkk / Edunomika Vol. 03, No. 01 (Februari 2019)

positif dan signifikan terhadap keputusan pembelian roti pada toko roti wonder bakery.

\section{d. Koefisien Determinasi (R2)}

Koefisiensi Determinasi untuk mengukur seberapa jauh variabel bebas dalam menerangkan suatu variabel yang terikat. Hasil dari suatu perhitungan dengan analisis linier berganda dapat diketahui bahwa besarnya koefisien determinasi (Adjusted $R^{2}$ ) yang diperoleh yaitu 0,625 atau 62,5\%. Hal ini menunjukan bahwa $62,5 \%$ keputusan pembelian roti pada toko wonder bakery dipengaruhi oleh variabel independen yang berupa variabel Produk, variabel brand image, dan variabel packaging. sedangkan sisanya sebesar $37.5 \%$ dipengaruhi oleh variabel lainnya diluar variabel penelitian ini.

\subsection{PEMBAHASAN}

Hasil penelitian menunjukan variabel produk $\left(X_{1}\right)$ diperoleh nilai $t$ hitung 6,999 dengan nilai signifikan 0,000 dan koefisien regresi Mempunyai nilai positif sebesar 0,489 berdasarkan hasil tersebut diperoleh keterangan bahwa variabel produk berpengaruh positif terhadap keputusan pembelian roti pada toko wonder bakery secara signifikan. Hal ini mengidentifikasi bahwa menjaga dan mempertahankan kualitas produk dengan sangat baik yang dilakukan oleh toko wonder bakery dalam memproduksi berbagai macam produk roti maka akan berdampak positif terhadap keputusan pembelian pada toko roti wonder bakery meningkat. Karena berdasarkan koefisien determinasi bahwa 37,5\% keputusan pembelian dipengaruhi selain variabel produk, brand image, dan packaging, maka dapat dipertimbangkan oleh para peneliti untuk membuat penelitian labih lanjut. Jackcon R.S Weenas (2013) menyatakan bahwa kua produk berpengaruh positif dan signifikan terhadap keputusan pembelian.

Hasil penelitian menunjukan variabel brand image $\left(\mathrm{X}_{2}\right)$ diperoleh nilai $\mathrm{t}$ hitung 4,823 dengan nilai signifikan 0,000 dan koefisien regresi mempunyai nilai positif sebesar 0,342 , berdasarkan hasil tesebut dapat diperoleh keterangan bahwa variabel brand image berpengaruh positif terhadap keputusan pembelian roti pada toko wonder bakery di Surakarta secara signifikan. Toko Roti Wonder Bakery sudah beroprasi selama puluhan tahun. Toko roti ini mula-mula membuka pertama kali di kota Salatiga dan memiliki citra yang baik di masyarakat. Seiring dengan meningkatnya laba perusahaan maka mereka membuka cabang di berbagai kota, salah satunya adalah di kota Solo. Cabang dikota Solo mula-mulanya hanya 1 yaitu di Jl. Gajahmada No. 132 A, Ketelan, Banjarsari, Kota Surakarta, Jawa Tengah 57132. Namun karena animo masyarakat kota Solo dan sekitarnya terhadap Toko Roti Wonder Bakery sangat baik maka perlu membuka cabang ke-2 yaitu di Jl. Dr. Rajiman No. 460, Bumi, Laweyan, Kota Surakarta, Jawa Tengah 5768. Hal ini membuktikan bahwa brand image dari Toko Roti Wonder Bakery berpengaruh signifikan terhadap keputusan pembelian konsumen Menurut Muhammad H.P. Wijaya mengemukakan bahwa Brand Image secara parsial berpengaruh terhadap keputusan pembelian. Nilai $t_{\text {hitung }}$ positif artinya pengaruh yang terjadi adalah positif artinya semakin tinggi brand image semakin meningkatkan keputusan pembelian.

Hasil penelitian menunjukan bahwa variabel Packaging $\left(\mathrm{X}_{3}\right)$ diperoleh nilai $\mathrm{t}_{\text {hitung }}$ 3,041 dengan nilai signifikan 0,005 dan koefisien regresi mempunyai nilai positif sebesar 0,197, berdasarkan hasil tesebut dapat diperoleh keterangan bahwa variabel Packaging berpengaruh positif terhadap keputusan pembelian konsumen pada toko Roti Wonder Bakery di Surakarta secara signifikan. Packaging yang tersedia di Toko Roti Wonder Bakery untuk membungkus/membawa produk-produk Roti Wonder Bakery sangat beragam. Contohnya mulai dari kardus roti berbagai ukuran, tas plastik, tas kardus dan toples beraneka bentuk. Disamping itu Toko Roti Wonder Bakery 
juga menyesuaikan desain yang terdapat didalam packaging dengan hari/perayaan tertentu. Misalkan untuk perayaan hari raya lebaran, Toko Roti Wonder Bakery akan membuat desain dengan tema lebaran dikardus pembungkusnya. Atau untuk pembelian roti dalam jumlah banyak yang ditujukan sebagai hantaran/oleh-oleh maka konsumen akan diberikan tas kertas/kardus dengan desain dan bahan yang cukup bagus dan diberikan secara cuma-cuma, sehingga memudahkan konsumen untuk membawa produknya. Hal ini membuktikan bahwa packaging memiliki pengaruh terhadap keputusan pembelian, karena ketika konsumen membeli barang yang pertama kali dilihat adalah packaging.

\section{KESIMPULAN DAN SARAN}

\subsection{Kesimpulan}

1) Hasil uji $\mathrm{F}$ menunjukan bahwa variabel produk $\left(\mathrm{X}_{1}\right)$, brand image $\left(\mathrm{X}_{2}\right)$, dan packaging $\left(\mathrm{X}_{3}\right)$ secara bersama-sama atau simultan berpengaruh signifikan lterhadap keputusan pembelian Toko Roti Wonder Bakery.

2) Hasil Uji $t$ menunjukan bahwa variabel produk secara parsial berpengaruh positif dan signifikan terhadap keputusan pembelianl Toko Roti Wonder Bakery di Surakarta, artinya semakin dikenal kualitas produk roti dengan memproduksi produk yang berkualitas baik.

3) Hasil uji t menunjukan bahwa variabel brand image secara parsial berpengaruh positif dan signifikan terhadap keputusan pembelian Toko Roti Wonder Bakery di Surakarta, artinya semakin baik brand image Toko Roti Wonder Bakery maka seorang konsomen mengetahui produk Roti Wonder Bakery dan berkeinginan untuk membeli produknya.

4) Hasil uji t menunjukan bahwa variabel packaging secara parsial berpengaruh positif dan signifikan terhadap keputusan pembelian Toko Roti Wonder Bakery di Surakarta, artinya semakin unik desain packaginng Toko Roti Wonder Bakery akan menambah konsumen dalam melakukan keputusan pembelian.

5) Variabel keputusan pembelian dapat dijelaskan oleh variabel produk $\left(\mathrm{X}_{1}\right)$, brand image $\left(\mathrm{X}_{2}\right)$ dan packaging $\left(\mathrm{X}_{3}\right)$ sebesar $62,5 \%$ dan sedangkan $37,5 \%$ dipengaruhi oleh variabel lainnya diluar penelitian ini.

\subsection{Saran}

1) Sebaiknya Tokol Roti Wonder Bakery memfokuskan atau menitik beratkan variabel produk, brand image dan packaging dalam menentukan strategi perusahaan karenal ketiga lvariable tersebut berpengaruh lterhadap keputusan pembelian.

2) Untuk menghadapi persaingan terutama dengan perusahaan roti sejenis, maka roti wonder bakery, hendaknya perlu memikirkan strategi supaya tidak kalah dalam persaingan dan tetap exsis.

3) Karena berdasarkan koefisien determinasi bahwa 37,5\% keputusan pembelian dipengaruhi selain variabel produk, brand image, dan packaging, maka dapat dipertimbangkan oleh para peneliti untuk membuat penelitian labih lanjut. 
Rangga Indra Fadilla, dkk / Edunomika Vol. 03, No. 01 (Februari 2019)

\section{DAFTAR PUSTAKA}

Mahera, Suharyono, Musadieq, 2014. Pengaruh International Brand Image dan kuaitas produk terhadap keputusan pembelian. Jurnal Administrasi Bisnis. Vol 8. No 1. Hal 1-8.

Weenas S.R Jackson. 2013. Kualitas Produk, Harga, Promosi Dan Kualitas Pelayanan Pengaruhnya Terhadap Keputusan Pembeelian Spring Bed Comforta. Jurnal Emba. Vol1. No 4. Hal 607618.

Hasyanto A Resty. 2013. Strategi Promosi, Kualitas Produk, Kualitas Pelayanan Terhadap Kepuasan Pelanggan Pada Restoran Mc. Donald Manado. Jurnal Emba. Vol 1, No 4. Hal 1465-1473 